\title{
PENGARUH PENGORGANISASIAN TERHADAP PENINGKATAN MUTU PENDIDIKAN DI SD INPRES BANGKALA II KOTA MAKASSAR
}

\author{
Ridwan Idris' ${ }^{1}$ Evi Lestari ${ }^{2}$ \\ 1,2Fakultas Tarbiyah dan Keguruan UIN Alauddin Makassar \\ 1,2Kampus II: Jalan H.M. Yasin Limpo Nomor 36 Samata-Gowa \\ Email: ridwan.idris@uin-alauddin.co.id ${ }^{1}$
}

\begin{abstract}
Abstrak:
Penelitian ini bertujuan untuk mengetahui gambaran pengorganisasian dan mutu pendidikandi SD Inpres Bangkala II Kota Makassar, dan untuk mengetahui pengaruh pengorganisasian terhadap peningkatan mutu pendidikan di sekolah tersebut. Penelitian ini menggunakan pendekatan kuantitatif dengan metode expost facto. Sampelnya adalah 17 tenaga pendidik dan kependidikan dari SD Inpres Bangkala II Kota Makassar. Data diperoleh melalui instrumen angket dan dokumentasi, dan dianalisis dengan menggunakan statistik deskriptif dan inferensial. Hasil penelitian menunjukkan bahwa pengorganisasian di SD Inpres Bangkala II Kota Makassar menunjukkan hasil yang belum maksimal atau berada pada kategori rendah $(58,82 \%)$ dan mutu pendidikan menunjukkan hasil yang baik yang berada pada kategori sedang $(100 \%)$. Hasil uji regresi menunjukkan pengorganisasian berpengaruh terhadap peningkatan mutu pendidikan sebesar $50 \%$. Ini berarti bahwa mutu pendidikan ditentukan oleh faktor lain. Faktor-faktor tersebut adalah perencanaan, pelaksanaan dan faktor evaluasi pembelajaran.
\end{abstract}

\begin{abstract}
:
This research aims at knowing the description of the organizationality and the quality of education in the elementary school of Inpres Bangkala II Makassar and knowing the effect of organizationality toward the education quality improvement in the school. This research was a quantitative approach using expost facto method. The sample was 17 teachers from the elementary school of Inpres Bangkala II Makassar. The data were collected using a questionnaire and documentation, and analyzed using descriptive and inferential statistics. The results of the research showed that the organizational structure of the school was in the low category $(52,82 \%)$ and the quality of education was in the medium category $(100 \%)$. The result of regression analysis showed that the organizational structure influenced the educational quality improvement of the school with $50 \%$ contribution. This means that the quality of education of that school was determined by other factors. Those factors were planning, implementation and evaluation.
\end{abstract}

Kata kunci:

Pengorganisasian, Mutu, Pendidikan

PENDIDIKAN merupakan hal yang sangat penting dalam kemajuan dunia dan manusia. Tidak ada batasan waktu bagi seseorang untuk terus belajar, yakni sejak lahir hingga seseorang tersebut meninggal dunia. Tidak hanya sebagai hal yang bisa membantu dalam perkembangan dunia, namun juga bisa menjadi sebuah titik tolak atau motivasi untuk bekal di akhirat kelak. 
Salah satu bagian penting pendidikan yang mempunyai peranan dalam mencapai tujuan pendidikan yaitu pengorganisasian. Seorang manajer sekolah harus mengetahui tujuan organisasi yang ingin dicapai, manajer perlu melakukan perincian kerja, pembagian kerja yang jelas, pengelompokan kerja, koordinasi pekerjaan, monitoring dan reorganisasi bagi semua pegawai yang menjadi bawahannya. Jika semua tugas ini dilaksanakan dengan baik maka kegiatan sekolah berjalan lancar dan tujuan dapat tercapai (Daryanto, 2006: 83). Pengorganisasian dilakukan berdasarkan tujuan dan program kerja sebagaimana dihasilkan dalam perencanaan.

Pengorganisasian memiliki prosedur sebagai: 1) Identifikasi pekerjaan, 2) Pengelompokan tugas, 3) Menyebutkan fungsi-fungsi pekerjaan atau tugas, 4) Pendelegasian wewenang, 5) Membuat aturan dalam pekerjaan, dan 6) Menetapkan setiap hubungan kerja.

Pendidikan termasuk produk jasa, dan dalam pendidikan selalu ada standar (kualitas) yang dirumuskan bersama oleh masyarakat dan diusulkan pada pemerintah untuk ditetapkan menjadi Peraturan Pemerintah, Peraturan Menteri, atau paling tidak Peraturan Daerah. Peraturan Pemerintah (PP) Nomor 19 Tahun 2005 dan direvisi menjadi PP Nomor 13 Tahun 2015 tentang standar nasional pendidikan menyebutkan bahwa:

Kualitas pendidikan di Indonesia diukur dengan delapan standar, yakni standar isi, standar proses, standar kompetensi lulusan, standar pendidik dan tenaga kependidikan, standar sarana dan prasarana, standar pengelolaan, standar pembiayaan; dan standar penilaian pendidikan (PP No. 13 Tahun 2015).

Delapan standar ini telah dijelaskan serta ditentukan ukuran-ukuran pencapaiannya yang telah ditetapkan dalam bentuk Peraturan Menteri Pendidikan Nasional. Dengan demikian, ukuran pencapaian kualitas pendidikan di Indonesia sangat ditentukan oleh pencapaian masing-masing sekolah dalam mengimplementasikan program dan proses layanan menuju pada standar minimal hasil pendidikan yang diharapkan dalam seluruh standar isi dan standar kompetensi lulusan, didukung dengan terpenuhinya standar proses, sarana dan parasarana, pengelolaan, penilaian, pembiayaan dan lain-lain.

Di era otonomi institusi pendidikan sekarang ini, tugas dan tanggung jawab untuk mewujudkan sekolah yang bermutu tak lepas dari bagaimana proses pengorganisasian, persyaratan, keterampilan, dan kompetensi seorang manajer dalam memimpin dan menjaga lembaganya bersama dengan semua bawahanya. Oleh karena itu seorang manajer sekolah sudah seharusnya mampu memperhatikan, memahami dan mengaplikasikan konsep-konsep ilmu manajemen termasuk pengorganisasian yang berkembang dewasa ini. Aplikasi pengorganisasian pada lembaga pendidikan untuk menciptakan sekolah yang dikelola agar menjadi lebih efektif dan efisien.

Direktorat TK dan SD, Ada lima komponen yang menentukan mutu pendidikan, yaitu: 1) Kegiatan belajar mengajar 2) Manajemen pendidikan yang efektif dan efisien 3) Buku dan sarana belajar yang memadai dan selalu dalam kondis siap pakai 4) Fisik dan penampilan sekolah yang baik 5) Partisipasi masyarakat (Bafadal, 2003: 20). 
Sekolah dasar harus dikelola dengan sebaik-baiknya sehingga menjadi sekolah dasar yang bermutu. Sebagai satuan pendidikan sekolah dasar tidak ubahnya sebagai sebuah institusi atau lembaga, dalam hal ini lembaga pendidikan yang mengemban misi tertentu dalam rangka mencapai tujuan kelembagaan (tujuan institusional pendidikan). Oleh karena itu sekolah dasar dikatakan bermutu baik apabila mampu mengemban misinya dalam rangka mencapai tujuan kelembagaannya. Sekolah dasar yang baik menurut direktorat taman kanak-kanak dan sekolah dasar, ada tiga misi yang diemban oleh setiap sekolah dasar, yaitu melakukan proses edukasi, proses sosialisasi dan proses transformasi.

Dengan demikian sekolah dasar dapat dikatakan baik apabila:

1. Menghasilkan lulusan terdidik (berbudi pekerti luhur), memiliki kedewasaan mental dan sosial, dan memiliki ilmu pengetahan dan teknologi, yang membuatnya siap memasuki sekolah lanjutan tingkat pertama.

2. Dalam menghasilkan lulusan yang dikehendaki tersebut maka perlu melalui proses edukasi, sosialisasi, dan transformasi yang baik pula dalam bentuk proses belajar mengajar yang bermutu (Bafadal, 2003: 21).

Atas dasar kerangka berpikir di atas, sekolah dasar yang bermutu baik adalah sekolah yang mampu berfungsi sebagai wadah proses edukasi,wadah proses sosialisasi, dan wadah transformasi, sehingga mampu mengantarkan anak didik menjadi seorang terdidik, memiliki kedewasaan mental dan sosial, serta memiliki ilmu pengetahuan dan teknologi, termasuk juga kebudayaan bangsa.

Permasalahan yang ada di SD Inpres Bangkala II Kota Makassar sejauh ini adalah kurangnya pengorganisasian dan mutu pendidikan yang masih rendah. Hal ini bisa terlihat dari pembagian tugas yang tidak jelas, pegawai yang tidak menjalankan tugasnya dengan baik, dan akreditas sekolah kurang dari harapan yaitu masih C. sehingga beberapa hal tersebut menghambat proses pelaksanan pendidikan dan peningkatan mutu di sekolah tersebut (Wawancaa dengan Karlina, Guru SDI Bangkala).

Dari uraian di atas bahwa jika proses pengorganisasian dilakukan dengan baik dan ilmiah, maka organisasi yang disusun akan baik, efektif, efisien dan sesuai dengan kebutuhan pendidikan dalam mencapai tujuanya, serta dapat meningkatkan mutu pendidikan (Hasibuan, 2008: 34). Hal inilah yang mendasari peneliti mengadakan penelitian untuk mengetahui adanya pengaruh pengorganisasian terhadap peningkatan mutu pendidikan di SD Inpres Bangkala II Kota Makassar.

\section{TINJAUAN TEORETIS}

\section{Pengorganisasian}

Pengorganisasian merupakan fungsi manajemen yang kedua dan merupakan langkah strategis untuk mewujudkan rencana. Suatu rencana yang telah dirumuskan dan ditetapkan sebagai hasil penyelenggaraan fungsi organik perencanaan, dilaksanakan oleh sekelompok orang yang bergabung dalam satuan-satuan kerja tertentu. Satuan-satuan kerja tersebut merupakan bagian dari organisasi. Karena berbagai kegiatan yang akan dilaksanakan baik yang berwujud tugas pokok maupun tugas pe- 
nunjang harus diusahakan agar terlaksana dengan efisien, efektif, dan produktif dalam satu wadah yang sesuai dengan kebutuhan, tidak mengherankan apabila para teoretikus manajemen menempatkan pengorganisasian sebagai fungsi organik manajerial yang segera mengikuti fungsi perencanaan (Siagian, 2007: 60).

Pengorganisasian dapat diartikan penentuan pekerjaan-pekerjaan yang harus dilakukan, pengelompokan tugas-tugas dan membagi-bagikan pekerjaan kepada setiap karyawan, penetapan departemen-departemen (subsistem-subsistem) serta penentuan hubungan-hubungan (Hasibuan, 2008: 22). Demikian pula pengorganisasian yang diungkapkan oleh Malayu S.P. Hasibuan pengorganisasian adalah suatu proses penentuan, pengelompokan dan pengaturan berbagai macam aktivitas dan menempatkan orang-orang pada setiap aktifitas itu kemudian menyiapkan alat-alat yang diperlukan dan terakhir menetapkan wewenang kepada setiap orang-orang yang akan melakukan aktivitas tersebut (Hasibuan, 2008: 23). Definisi senada juga diungkap oleh Sondang (2007: 60) dan Terry (2003: 72).

Dalam bahasa Arab, pengorganisasian diistilahkan dengan al-Tandhim. Menurut Mahmud Hawary pengorganisasian adalah Menjalankan segala sesuatu sesuai dengan fungsinya, demikian juga setiap anggota berada sesuai dengan fungsinya, dan merupakan ikatan dari perorangan terhadap yang lain, guna melakukan kesatuan tindakan yang tepat, menuju suksesnya fungsi masing-masing (Al-Hawary, 1976: 189).

Berdasarkan beberapa pendapat di atas memberi pengertian bahwa pengorganisasian merupakan usaha penciptaan hubungan tugas yang jelas antara personalia, sehingga setiap orang dapat bekerja bersama-sama dalam kondisi yang baik untuk mencapai tujuan-tujuan organisasi.

\section{Mutu Pendidikan}

Secara bahasa, peningkatan mutu terdiri dari dua kata yaitu peningkatan dan mutu. Kata peningkatan memiliki arti proses, cara, atau perbuatan meningkatkan usaha, kegiatan, dan lain-lain (Tim Penyusun Kamus Pusat Pembinaan dan Pengembangan Bahasa, 1989: 951). Sedangkan kata mutu artinya kualitas atau (ukuran) baik buruk suatu benda, kadar, taraf atau derajat (kepandaian, kecerdasan, dan sebagainya) (Tim Penyusun Kamus Pusat Pembinaan dan Pengembangan Bahasa, 1989: 604).

Terdapat beragam pemahaman tentang makna kualitas (mutu) yang kemudian dirumuskan dalam beberapa pendapat yang berbeda, tetapi mempunyai pemahaman yang sama.

Parrsley dan Carrigan yang dikutip oleh Kompri mengemukakan bahwa:

Istilah kualitas mengandung nilai yang sangat penting, walupun setiap orang dapat memberikan pengertian berbeda cara penafsirannya, misalnya memeahami istilah kualitas diartikan sebagi unggulan atau istilah lain pencapaian standar sempurna yang berawal dari penilaian standar minimum, atau sesuatu yang hanya memiliki kesalahan kecil dapat diterima (Kompri, 2015: 150).

Sukmadinata yang dikutip oleh Kompri mengemukakan bahwa: 
Mutu pendidikan bersifat meyeluruh, menyangkut komponen, pelaksanaan, dan kegiatan pendidikan, atau disebut sebagai mutu total atau total quality. Hasil pendidikan yang bermutu tidak hanya didapat dengan satu komponen saja yang dicapai atau kegiatan pendidikan yang bermutu. Kegiatan pendidikan cukup kompleks, satu kegiatan, komponen, pelaku, waktu terkait, dan membutuhkan dukungan dari kegiatan, komponen, pelaku serta waktu lainya (Kompri, 2015: 156).

Lebih lanjut berkenaan dengan pelayanan, ini juga selaras dengan hadits Rasulullah saw, beliau memerintahkan kepada kita agar berusaha untuk menjadi manusia yang bermanfaat bagi sesama, dalam hal ini beliau sampaikan dalam HR Thabrani dan Daruqutni sebagai berikut:

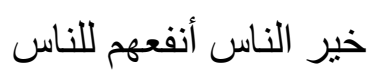

Sebaik-baik manusia adalah yang paling bermanfaat bagi sesamanya (www.risalahislam.com).

Mutu pendidikan bersifat relatif karena tidak semua orang memiliki ukuran yang sama persis. Namun demikian apabila mengacu pada pengertian mutu secara umum dapat dinnyatakan bahwa pendidikan yang bermutu adalah pendidikan yang seluruh komponenya memiliki persyaratan dan ketentuan yang diinginkan pelanggan dan menimbulkan kepuasan. Mutu pendidikan adalah baik, jika pendidikan tersebut dapat menyajikan jasa yang sesuai dengan kebutuhan para pelangganya.

Dari definisi tersebut dapat diambil kesimpulan bahwa mutu adalah keadaan yang sesuai dan melebihi harapan pelanggan hingga pelaggan memperoleh kepuasan. Dengan demikian dalam hal mutu pendidikan, internal sekolah harus memperhatikan pelayanan yang baik sehingga pelaggan eksternal memperoleh kepuasan terhadap pelayanan yang diberikan.

Stadar mutu pendidikan dapat dirujuk dari standar nasional pendidikan yang telah ditetapkan kriteria minimal tentang sistem pendidikan di Indonesia meliputi:

1. Standar kompetensi lulusan yaitu stanar nasional pendidikan yang berkaitan dengan kemampuan minimal yang mencakup pengetahuan, keterampilan dan sikap yang wajib dimiliki peserta didik untuk dapat dinyatakan lulus

2. Standar isi adalah standar nasional pendidikan yang berkaitan dengan cakupan ke dalam materi pelajaran untuk mencapai standar kompetensi lulusan yang dituangkan ke dalam ompetensi bahan kajian, kompetensi mata pelajaran, dan silabus pembelajaran.

3. Standar proses adalah standar nasional pendidikan yang berkaitan dengan prosedur dan pengorganisasian pengalaman belajar untuk mencapai standar kompeensi lulusan. Standar proses pedidikan yang membudayakan dan menjunjung tinggi HAM, nilai keagamaan, budaya, dan kemajemukan. Proses pendidikan pada setiap satuan pendidikan diselenggarakan dengan member kan keteladanan, membangun kemauan, dan mengembangkan kreativitas dan kemandirian peserta didik sesuai dengan perkembangan, kecerdasan, dan kemandirian dalam rangka pencapaian standar kompetensi lulusan. 
4. Standar pendidik dan tenaga kependidikan adalah standar nasional pendidikan yang berkaitan dengan kualifikasi minimal yang harus dipenuhi oleh setiap pendidik dan tenaga kependidikan, yang harus memiliki 4 kompetensi yaiti kompetensi pedagogik, kepribadian, professional, dan sosial.

5. Standar sarana dan prasarana adalah standar nasional pendidikan yang berkaitan dengan prasyarat minimal tentang fasilitas fisik yang diperlukan untuk mencapai standar kompetensi lulusan.

6. Standar pengelolaan adalah standar nasional pendidikan yang berkaitan dengan perencanaan , pelaksanaan, evaluasi, pelaporan, dan pengawasan kegiatan agar tercapai efesiensi dan efektifitas penyelenggaraan pendidikan.

7. Standar pembiayaan adalah standar nasional pendidikan yang berkaitan dengan biaya untuk penyelenggaraan satuan pendidikan.

8. Standar penilaian pendidikan adalah standar nasional pendidikan yang berkaitan dengan mekanisme, prosedur, dan alat penilaian pendidikan (Komariah dan Engkoswara, 2012: 311).

Berdasarkan beberapa pernyataan di atas, maka mutu pendidikan di sekolah dapat diartikan sebagai kemampuan sekolah dalam pengelolaan secara operasional dan efisien terhadap komponen-komponen yang berkaitan dengan sekolah, sehingga menghasilkan nilai tambah terhadap komponen tersebut menurut norma atau standar yang berlaku.

\section{METODOLOGI PENELITIAN}

\section{Jenis dan Lokasi Penelitian}

Jenis penelitian dalam penelitian ini adalah berdasarkan metode expost facto, dan dilakukan pada tenaga pendidikan dan kependidikan di SD Inpres Bangkala II Kota Makassar.

\section{Pendekatan Penelitian}

Pendekatan dalam penelitian ini adalah pendekatan kuantitatif. Menurut Sugiyono menjelaskan bahwa pendekatan kuantitatif dapat diartikan sebagai metode penelitian yang berlandaskan pada filsafat positivisme, dan digunakan untuk meneliti pada populasi atau sampel tertentu, pengumpulan data menggunakan instrument penelitian, analisis data bersifat kuantitatif atau statistik, dengan tujuan untuk menguji hipotesis yang telah ditentukan (Sugiyono, 2014: 35).

\section{Populasi dan Sampel}

Populasi atau sumber data dalam penelitian ini adalah pengelola pendidikan di SD Inpres Bangkala II Kota Makassar yang terdiri dari tenaga pendidik dan kependidikan (honor dan PNS) berjumlah 16 orang dan 1 Kepala sekolah, keseluruhan berjumlah 17 orang, yang berdasarkan data administrasi (sistem informasi tata usaha) SD Inpres Bangkala II Kota Makassar. Sedangkan sampel dilakukan dengan mengambil sampel yang ada di SD Inpres Bangkala II Kota Makassar yang berjumlah 17 orang yaitu tenaga pendidik dan kependidikan. 


\section{Metode dan Instrumen Penelitian}

Untuk mengumpulkan data dalam penulisan skripsi ini, maka peneliti menggunakan metode Angket dan dokumentasi. Sedangkan instrumen yang digunakan adalah; pedoman angket atau kuesioner yang terdiri atas Skala Pengorganisasian dan Skala Mutu Pendidikan dan pedoman dokumentasi

\section{Teknik Analisis Data}

Setelah data terkumpul, maka selanjutnya dilakukan analisis data. Analisis data yang akan digunakan dalam penelitian ini yaitu: teknik analisis statistik deskriptif dan Teknik Analisis Statistik Inferensial.

\section{HASIL DAN PEMBAHASAN PENELITIAN}

\section{Deskripsi Pengorganisasian di SD Inpres Bangkala II Kota Makassar}

Hasil penelitian ini menunjukan gambaran pengorganisasian di SD Inpres Bangkala II Kota Makassar, dan diketahui bahwa 10 atau 58,82\% responden yang berada dalam kategori rendah, dan 1 atau 5,88\% responden yang barada dalam kategori sedang, serta 6 atau 35,30\% responden yang barada dalam kategori tinggi. Sementara itu, nilai rata-rata yang diperoleh sebesar 121,9 apabila dimasukkan dalam ketiga kategori pengorganisasian, maka nilai tersebut berada pada interval $X<119$ yaitu dalam kategori rendah. Sehingga dapat disimpulkan bahwa pengorganisasian di SD Inpres Bangkala II Kota Makassar berada dalam kategori rendah yakni 58,82\%.

Salah satu bagian penting pendidikan yang mempunyai peranan dalam mencapai tujuan pendidikan yaitu pengorganisasian. Seorang manajer sekolah harus mengetahui tujuan organisasi yang ingin dicapai, manajer perlu melakukan perincian kerja, pembagian kerja yang jelas, pengelompokan kerja, koordinasi pekerjaan, monitoring dan reorganisasi bagi semua pegawai yang menjadi bawahannya. Jika semua tugas ini dilaksanakan dengan baik maka kegiatan sekolah berjalan lancar dan tujuan dapat tercapai. Kemudian jika dilihat hasil penelitian ini juga selaras dengan penelitian Andi Hajar tentang Aplikasi pengorganisasian dalam kepemimpinan di SMAN 1 Watampone, dan hasil penelitian tersebut menyatakan bahwa aplikasi fungsi pengorganisasian di SMAN 1 Watampone menunjukkan hasil yang baik (Andi Hajar, Skripsi, 2009).

Seperti yang kita ketahui bahwa pengorganisasian adalah fungsi manajemen dan merupakan suatu proses yang dinamis, pengorganisasian dapat diartikan sebagai penentuan pekerjaan-pekerjaan yang harus dilakukan, pengelompokan tugas-tugas dan membagi-bagikan pekerjaan kepada setiap karyawan, penetapan departemen-departemen (subsistem-subsistem) serta penentuan hubungan-hubungan, jika pengorganisasian dilakukan dengan maksimal maka kegiatan atau tugas-tugas akan berjalan dengan baik sehingga tidak ada penumpukan pekerjaan akibat rancuhnya penentuan, pengelompokan, pembagian, perincian tugas-tugas yang akan dilakukan oleh karyawan, bahkan akan menyebabkan tujuan yang telah direncanakan tidak tercapai. Dengan demikian salah satu fungsi manajemen yaitu pengorganisasian turut berperan dalam tercapainya keberhasilan atau kualitas suatu lembaga pendidikan khususnya. 
Dalam pengorganisasian yang diteliti di SD Inpres Bangkala II Kota Makassar berada pada taraf yang rendah yaitu sebesar $58,82 \%$, ini terlihat dari pembagian tugas yang tidak jelas, dan pegawai yang tidak menjalankan tugasnya dengan baik. Dari persentasi yang didapatkan peneliti yaitu 58,82\% sisanya $41,81 \%$. Artinya sebesar $41,81 \%$ ada faktor lain yang mempengaruhi mutu pendidikan. Adapun faktor lain yang mempengaruhi mutu pendidikan selain pengorganisasian, Menurut peneliti adalah faktor perencanaan, pelaksanaan dan faktor evaluasi pembelajaran.

Perencanaan atau planning dapat didefinisikan sebagai keseluruhan proses pemikiran dan penentuan secara matang tentang hal-hal yang akan dikerjakan di masa yang akan datang dalam rangka pencapaian tujuan yang telah ditentukan.

Fakhry Gaffar menguraikan bahwa:

Perencanaan sebagai proses penyusunan berbagai keputusan yang akan dilaksanakan pada masa yang akan datang untuk mencapai tujuan yang ditentukan. Keputusan-keputusan itu disusun secara sistematis, rasional, dan dapat dibenarkan secara ilmiah karena menerapkan berbagai pengetahuan yang diperlukan (Saefullah, 2012: 214).

Perencanaan menjadi fungsi organik pertama karena merupakan dasar dan titik tolak dari kegiatan pelaksanaan selanjutnya. Alasannya bahwa tanpa adanya rencana, maka tidak ada dasar untuk melaksanakan kegiatan-kegiatan tertentu dalam rangka usaha pencapaian tujuan. Dengan demikian kepala sekolah harus mampu merencanakan kegiatan-kegiatan atau membuat strategi untuk mencapai tujuan sesuai dengan tujuan pendidikan, melalui perencanaan hal ini sangatlah berpengaruh untuk meningkatkan mutu pendidikan secara efisien untuk mewujudkan pendidikan yang baik. Setelah membuat perencanaan yang matang setelah itu kepala sekolah melakukan pengorganisasian. Lebih lanjut dipaparkan oleh Djemari bahwa mutu pendidikan didukung oleh faktor evaluasi pembelajaran, pembelajaran dikatakan sebagai program karena melibatkan banyak komponen, seperti guru, peserta didik, sarana prasarana dalam pelaksanaannya, agar berjalan dengan baik, maka seorang pendidik harus mampu mengelola seluruh aspek input dengan baik (www.researchgate.net).

Dengan demikian perlu melaksanakan evaluasi terhadap program pembelajaran yang telah berjalan, dengan tujuan untuk melihat sejauh mana program pembelajaran mempengaruhi peningkatan mutu Pendidikan.

\section{Deskripsi Mutu Pendididikan di SD Inpres Bangkala II Kota Makassar}

Berdasarkan hasil analisis deskriptif gambaran mutu pendidikan di SD Inpres Bangkala II Kota Makassar, diketahui bahwa 17 tenaga pendidik dan tenaga kependidikan sebagai sampel, 0 atau $0 \%$ responden yang barada dalam kategori sedang, dan 17 atau $100 \%$ responden yang barada dalam kategori sedang, serta 0 atau $0 \%$ responden yang barada dalam kategori tinggi. itu, nilai rata-rata yang diperoleh sebesar 113,97 . Apabila dimasukan dalam ketiga kategori mutu pendidikan, maka nilai tersebut berada pada interval $97 \leq X<129$ yaitu dalam kategori sedang. Hal tersebut menggambarkan bahwa, mutu pendidikan di SD Inpres Bangkala II Kota Makassar berada dalam kategori sedang yakni $100 \%$. 
Berdasarkan hasil penelitian di atas dapat diketahui bahwa semakin bagus mutu atau kualitas kinerja pendidik dan tenaga kependidikan dalam bidang pendidikan dan pengajaran, maka akan semakin tinggi tingkat pemenuhan kebutuhan dan kepuasan pelanggan internal dan eksternal. Mutu pendidikan yang baik sebenarnya di pengaruhi oleh banyak faktor, dan salah satunya faktor yang paling menunjang peningkatan mutu adalah adanya dukungan penuh dari lembaga pendidikan terkait dengan kebutuhan semua aspek yang menunjang peningkatan mutu pendidikan seperti; pelatihan, workshop, pemenuhan sarana dan prasarana pembelajaran, tenaga pendidik dan kependidikan yang memiliki 1) Professionalism and skill, 2) Atitude and behavior, 3) Accessibility and Flexibility, 4) Reability and trustworthiness, 5) Recovery, 6) Reputation and Credibility (Engkoswara dan Aan Komariah, 2012: 305).

Lebih lanjut berkenaan dengan hasil pembahasan penelitian tentang mutu pendidikan ini juga selaras dengan penelitianya Mawadi, tentang upaya peningkatan mutu pendidikan Di MAN Maguwoharjo Sleman Yogyakarta" kesimpulan dari penelitian tersebut menunjukkan: 1) Kepala sekolah sebagai pucuk kepemimpinan pendidikan, mengajak bekerja sama terhadap semua pihak baik orang tua siswa, warga sekolah, masyarakat, stakeholder dan intansi swasta maupun pemerintah, 2) dalam upaya peningkatan mutu pendidikan di madrasah tersebut maka guru diberikan tugas untuk meningkatkan kreativitas dan inovasi dalam belajar mengajar, 3) sebagai upaya peningkatan mutu pendidikan, madrasah membangun diri bagi semua warga sekolah untuk disiplin, harmonis dan saling memotivasi antara satu dengan yang lain, 4) adanya usaha-usaha untuk meningkatkan sarana dan prasarana sebagai pendukung kegiatan belajar yang efektif dan efesien, dan upaya mutu pendidikan tersebut menunjukkan hasil yang baik (Mawadi, http://digilib.uin-suka.ac.id).

Sejatinya sekolah dasar yang bermutu baik adalah sekolah yang mampu berfungsi sebagai wadah proses edukasi, wadah proses sosialisasi, dan wadah transformasi, sehingga mampu mengantarkan peserta didik menjadi seorang terdidik, memiliki kedewasaan mental dan sosial, serta memiliki ilmu pengetahuan dan teknologi, termasuk juga kebudayaan bangsa.

Berdasarkan hasil penelitian, gambaran mutu pendidikan di SD Inpres Bangkala II Kota Makassar berada dalam kategori sedang. Menurut peneliti sekolah yang belum maksimal dan memuaskan adalah terletak pada standar tenaga pendidik dan kependidikan serta sarana dan prasarana. Hal ini diperparah dengan belum ada kepedulian dan upaya pihak sekolah untuk memacu dan meningkatkan mutu mereka dengan mengatasi permasalahan ini.

Agar mutu tetap terjaga dan proses peningkatan mutu tetap terkontrol harus ada standar yang mengatur dan disepakati secara nasional untuk dijadikan indikator evaluasi keberhasilan peningkatan mutu tersebut (adanya banchmarking). Pemikiran seperti ini telah mendorong munculnya pendekatan baru, yakni pengelolaan peningkatan mutu pendidikan yang mampu memberdayakan semua sumber daya agar memiliki sekolah yang efektif sehingga tujuan sekolah dapat tercapai. 
Salah satu hal yang harus diperhatikan oleh seorang pemimpin pendidikan adalah mutu lembaga pendidikan. Karena seluruh manajemen komponen pendidikan senantiasa berorientasi pada pencapaian mutu. Semua program kegiatan pendidikan dan pembelajaran di lembaga pendidikan pada hakikatnaya diarahkan pada pencapaian mutu. Sekolah yang efektif dan bermutu harus dimulai dengan kerja keras dan semua komponen sekolah mau dan mampu untuk aktif dengan program kegiatan, mulai dari perencanaan, proses sampai dengan evaluasi dengan sungguh-sungguh.

\section{Pengaruh Pengorganisasian terhadap Peningkatan Mutu Pendidikan}

Berdasarkan hasil statistik inferensial pengujian hipotesis yang memperlihatkan bahwa untuk uji signifikansi yaitu, Jika $\mathrm{t}_{\mathrm{b}}<\mathrm{t}_{\mathrm{tab}}$ atau $\mathrm{H}_{0}$ diterima, hal ini berarti konstanta persamaan regresi tidak signifikan. Sedangkan $t_{b}>t_{\text {tab }}$ atau $H_{0}$ ditolak atau koefisien regresi bersifat signifikan.

Dari hasil perhitungan diperoleh $t_{\text {hitung }}=155,8$ sementara $t_{\text {tabel }}=2,13$ untuk taraf signifikansi $5 \%$. Karena $t_{\text {hitung }}$ lebih besar dari $t_{\text {tabel }}$ maka dapat disimpulkan bahwa Ho ditolak dan Ha diterima. Sehingga terdapat pengaruh yang signifikan antara pengorganisasian terhadap peningkatan mutu pendidikan di SD Inpres Bangkala II Kota Makassar.

Selanjutnya dari pengaruh hasil penelitian ini menunjukkan bahwa ternyata ada pengaruh yang signifikan antara pengorganisasian terhadap peningkatan mutu pendidikan di SD Inpres Bangkala II Kota Makassar. Selain itu, besarnya pengaruh variabel $X$ dengan $Y$ adalah $50 \%$.

Hal ini juga selaras dengan penelitian Normawati dengan judul: "Manajemen Mutu Pendidikan (Studi Kasus Pada Madrasah Aliyah Negeri 2 Model Palu)" tahun 2015, berdasarkan penelitian tersebut bisa ditarik kesimpulan bahwa penerapan MBS di Madrasah Aliyah Negeri 2 Model Palu sudah terlaksana dengan cukup baik, karena sekolah tersebut ternyata telah menjadi MAN percontohan di daerahnya (Normawati, Disertasi, 2015: 39-60). Selaras juga dengan penelitian Andi Hajar dengan judul aplikasi fungsi pengorganisasian dalam kepemimpinan di SMAN 1 Watampone pada tahun 2009 (Andi Hajar, Skripsi, 2009). Berdasarkan kesimpulan tersebut maka bisa diketahui salah satu faktor peningkatan kualitas pendidikan adalah fungsi pengorganisasian yang diatur oleh kepala sekolah dengan efektif dan efesien sehingga pendidikan tersebut menunjukkan hasil yang memuaskan.

\section{SIMPULAN DAN SARAN}

Berdasarkan hasil analisis data dan pembahasan yang telah dijelaskan di subbab sebelumnya, maka penelitian ini dapat disimpulkan sebagai berikut:

1. Penelitian Pengorganisasian pada SD Inpres Bangkala II Kota Makassar, yang dilihat dari hasil penilaian 17 responden tentang pengorganisasian tenaga pendidik dan kependidikan berada dalam kategori rendah, yakni 58,82\%. Hal ini mengindikasikan bahwa pengorganisasian dengan indikator tersebut diatas belum maksimal. 
2. Mutu Pendidikan pada SD Inpres Bangkala II Kota Makassar, yang dilihat dari hasil penilaian 17 responden berada pada kategori sedang, yakni 100\%. Hal ini mengindikasikan bahwa mutu pendidikan dengan indikator tersebut diatas sudah cukup baik. Dari hasil perhitungan diperoleh $t_{\text {hitung }}=155,8$ sementara $t_{\text {tabel }}=2,13$ untuk taraf signifikansi $5 \%$. Karena $t_{\text {hitung }}$ lebih besar dari $t_{\text {tabel }}$ maka dapat disimpulkan bahwa Ho dtolak dan Ha diterima. Sehingga terdapat pengaruh yang signifikan antara pengorganisasian terhadap peningkatan mutu pendidikan di SD Inpres Bangkala II Kota Makassar.

3. Besarnya pengaruh pengorganisasian terhadap peningkatan mutu pendidikan sebesar $50 \%$, dengan demikian mutu pendidikan $50 \%$ dipengaruhi oleh faktor lain. Adapun faktor yang mempengaruhi mutu pendidikan selain pengorganisasian, menurut peneliti adalah faktor perencanaan, pelaksanaan dan faktor evaluasi pembelajaran. Mengapa demikian, karena faktor-faktor tersebut jika fungsikan secara maksimal maka pendidikan akan menunjukkan hasil yang memuaskan.

Implikasi penelitian ini dapat dijadikan literatur atau referensi tambahan dan sebagai wacana, serta masukan mengenai pengaruh pengorganisasian terhadap peningkatan mutu pendidikan bahwa dengan pengorganisasian yang optimal akan mempengaruhi mutu pendidikan yang baik, sehingga terwujudlah sekolah yang unggul, pendidikan yang memiliki kemampuan dan membentuk watak serta peradaban bangsa yang bermartabat dalam rangka mencerdaskan kehidupan bangsa.

Berdasarkan apa yang telah disimpulkan dari hasil penelitian ini, maka penulis memiliki beberapa saran yang mungkin dapat dilaksanakan untuk meningkatkan pengorganisasian terhadap peningkatan mutu pendidikan sebagai berikut:

1. Mengingat pengorganisasian berpengaruh terhadap mutu pendidikan, hendaknya pihak pimpinan dalam hal ini kepala sekolah SD Inpres Bangkala II Kota Makassar berusaha memperhatikan proses pelaksanaan fungsi manajerial dan kepemimpinan dengan optimal, bukan hanya pengorganisasian yang baik namun mulai dari perencanaan, pelaksanaan, dan pengontrolan.

2. Pimpinan sekolah hendaknya memberikan evaluasi secara berkesinambungan tentang mutu atau kualitas sekolah, agar lembaga pendidikan yang dipimpinnya sesuai dengan kebutuhan dan harapan pelanggan internal maupun eksternal.

3. Perlu diadakan penelitiaan lebih lanjut dan mendalam, dengan jumlah sampel yang lebih besar lagi tentang pengaruh pengorganisasian terhadap peningkatan mutu pendidikan, serta faktor-faktor lain yang menunjang peningkatan mutu pendidikan yaitu faktor perencanaan dan evaluasi pembelajaran.

\section{DAFTAR PUSTAKA}

Arikunto, S. (2002). Prosedur penelitian. Jakarta: PT Rineka Cipta.

Arifin, S. (2016). Eksperime-expost-facto-korelasional-komparatif. Kompasiana, 20 Agustus 2016.

Azwar, S. (2015). Penyusunan Skala Psikologi. Yogyakarta; Pustaka Pelajar.

Al-Qurtubi, S. (2005). Jami' al-Bayân li al-Ahkâm al-Qur'an, juz 1, Mauqi'u al-Tafâsir: Dalam Software Maktabah Samilah. 
Bafadal, I. (2003). Manajemen Peningkatan Mutu Sekolah Dasar. Jakarta: PT. Bumi Aksara.

Daryanto. (2006). Administrasi Pendidikan. Jakarta: PT Rineka Cipta.

Departemen Agama RI. (2006). Al-Qur'an dan Terjemahan. Jakarta.

Effendi, S. \& Masri S. (1995). Metode Penelitian Survey. Jakarta.

Edward, S. (2011). Manajemen Mutu Terpadu Pendidikan. Yogjakarta: IRCiSoD.

Hajar, A. (2009). "Aplikasi Fungsi Pengorganisasian Dalam Kepemimipinan Di SMA Negeri 1 Watampone." Skripsi, Makassar: Fak. Tarbiyah dan Keguruan UIN Alauddin.

http://www.risalahislam.com/2014/02/manusia-terbaik-paling-bermanfaat ramah.html?m=1. Diakses pukul 17.47 WITA, 14 maret 2017.

http:// digilib.uin-suka.ac.id/837/1/BAB\%20I,\%20BAB\%20IV,\%20DP.pdf diakses 06 Februari 2017. Diakses pukul 18.21 WITA.

https://www.researchgate.net/publication/316281230_Evaluasi_Program_Pembelajaran_dal am_Meningkatkan_Mutu_Pendidikan. Diakses 15 Agustus 2017 pukul 22.22 WITA.

Indonesia, Republik, “Undang-Undang Dasar 1945 No. 20 Tahun 2003. Pasal 3," dalam ABD.

Jamiluddin. (2017). “Manajemen Pengorganisasian Yayasan Hasyim Asy'ari Yogyakarta”, Blog Jamiludin, http://digilib.uin suka.ac.id, diakses (06 februari 2017) pukul 22.22 wita.

Kadir. (2015). Statistika Terapan. Jakarta: Rajawali Pers.

Karlina. (2016). Guru SD Inpres Bangkala II Kota Makassar. Mei 2016.

Komariah, Aan, dan Engkoswara. (2012). Andministrasi Pendidikan. Bandung: Alvabeta.

Kompri. (2015). Manajemen Pendidikan. Bandung: Alvabeta.

Malayu, H. (2008). Organisasi dan Motivasi. Jakarta: PT Bumi Aksara.

Mawadi. "Upaya Peningkatan Mutu Pendidikan di MAN Maguwoharjo Sleman Yogyakarta."

Mahmud, S. (1976). Al-Hawary Idârah al-Asâs wa al-Ushul al-Ilmiyah. Dar al-Kutub: Mesir.

Nasution, S. (2011). Sosiologi Pendidikan. Jakarta: PT Bumi Aksara.

Nasution, S. Metode Research (Penelitian Ilmiah). Jakarta: Bumi Aksara.

Nawawi, H. (2003). Manajemen Strategi Organisasi Non Profit Bidang Pemerintahan dengan Ilustrasi Di Bidang Pendidikan. Yogyakarta: Gadja Mada.

Normawati. (2015). “Manajemen Mutu Pendidikan (Studi Kasus Pada Madrasah Aliyah Negeri 2 Model Palu)." Disertasi, Bidang Pendidikan dan Keguruan PPs UIN Alauddin Makassar.

Peraturan Pemerintah No. 13 tahun 2015, Pasal 2 ayat 1 revisi atas Peraturan Pemerintah No. 19 tahun 2005.

Riduwan. (2008). Belajar Mudah Penelitian Untuk Guru, Karyawan, dan Peneliti Pemula. Bandung. Republik Indonesia. “Undang-Undang Dasar 1945 No. 20 Tahun 2003. Pasal 3,” dalam ABD.

Sagala, S. (2011). Manajemen Startejik dalam Peningkatan Mutu Pendidikan, Bandung: Alfabeta.

Saefullah. (2012). Manajemen Pendidikan Islam. Bandung: Pustaka Setia.

Siagian, S. P. (2007). Fungsi-fungsi Manajerial. Jakarta: PT Bumi Aksara.

Siswanto. (2009). Pengantar Manajemen. Jakarta: PT Bumi Aksara.

Shihab, Q. (2006). Tafsir Al-Misbah, Pesan, Kesan dan Keserasian Al-Qur'an (Volume 11). Jakarta: Lentera Hati, Cet. IV.

Subana, dkk. (2000). Statistik Pendidikan. Bandung: CV Pustaka Setia.

Suryadi. (2009). Manajemen Mutu Berbasis Sekolah. Jakarta: PT Sarana Panca Karya Nusa.

Sugiyono. (2014). Metode Penelitian Manajemen. Bandung: Alfabeta.

Sugiyono. (2014). Metode Penelitian Pendidikan; Pendekatan Kuantitatif, Kualitatif dan $R$ \& D. Bandung: Alfabeta.

Syamsudduha. (2004). Manajemen Pesantren Teori dan Praktek. Yogyakarta: Graha Guru.

Syukur, F. (2013). Manajemen Pendidikan. Semarang: PT Pustaka Rizki Putra. 
Tim, Dosen. (2012). Administrasi Pendidikan Universitas Pendidikan Indonesia. Manajemen Pendidikan, Bandung: Alvabeta.

Tim Penyusun Kamus Pusat Pembinaan dan Pengembangan Bahasa. (1989). Kamus Besar Bahasa Indonesia, Cet. 2 ;Jakarta: Balai Pustaka.

Terry. (2003). Prinsip-Prinsip Manajemen. Jakarta: Bumi Aksara.

Thabran-AL. (2005). Mu'jâm al-Ausâth, juz 2, (Mauqi'u al-Islam: Dalam Software Maktabah Syamilah.

Usman, H. (2006). Manajemen Teori, Praktik, dan Riset Pendidikan. Jakarta: PT Bumi Aksara.

Umar bin Muhammad, Ar-Razi, Tafsir Ar-Râzi, (dalam Software Maktabah Syamilah, Juz 8

Widoyoko, S. E. P. (2014). Teknik Penyusunan Instrumen Penelitian, Yogyakarta: Pustaka Pelajar. 